\title{
TRADE STRATEGY, INVESTMENT AND EXPORTS: ANOTHER LOOK AT EAST ASIA
}

\author{
Dani Rodrik
}

Working Paper 5339

\section{NATIONAL BUREAU OF ECONOMIC RESEARCH 1050 Massachusetts Avenue \\ Cambridge, MA 02138 \\ November 1995}

This paper was prepared under a cooperative agreement between the Institute for Policy Reform (IPR) and the Agency for International Development (AID), Cooperative Agreement No. PDC0095-A-00-1126-00. This paper is part of NBER's research programs in Growth, and International Trade and Investment. Any opinions expressed are those of the author and not those of the IPR, AID, or the National Bureau of Economic Research.

() 1995 by Dani Rodrik. All rights reserved. Short sections of text, not to exceed two paragraphs, may be quoted without explicit permission provided that full credit, including $\mathbb{C}$ notice, is given to the source. 


\begin{abstract}
The export booms in South Korea and Taiwan starting in the early 1960s are anomalous when compared with later export booms in other, non-East Asian countries such as Chile and Turkey. First, these booms have taken place in the context of comparatively small changes in relative prices in favor of exportables. Second, they have been associated from the start with booms in investment. This paper offers an argument and a formal model to suggest that exports in East Asia may have been driven by an increase in the profitability of investment, with outward orientation a consequence of the investment boom rather than its instigator. In economies like South Korea and Taiwan, an increase in investment required an increase in imports of capital goods. Since savings rose alongside the desired investment, the investment boom was accompanied by a boom in both exports and imports. Moreover, this could happen with a relatively small change in the relative price of exportables.
\end{abstract}

\title{
Dani Rodrik
}

Department of Economics

Columbia University

420 West 118th Street, Room 1312

New York, NY 10027

and NBER 


\section{Introduction}

An export-oriented strategy figures prominently in most explanations of the East Asian miracle. By now, every college undergraduate in economics is taught a story along the following lines. Prior to the early 1960s, South Korea and Taiwan followed import-substitution policies with high rates of import protection, multiple and overvalued exchange rates, and repressed financial markets. These policies, also adopted by most other developing countries at the time, were jettisoned in the late 1950 s and 1960 s in favor of export-oriented policies which greatly reduced (or eliminated) the anti-export bias of their trade regimes. The reforms involved devaluations, currency unification, and export subsidization, along with moderate amounts of import liberalization. These policies allowed South Korea and Taiwan to specialize along their comparative advantage and to benefit from expanded trade. Greater openness in turn fostered technological improvements, increased private investment, and a high rate of economic growth. Along with the debt crisis, the success of East Asian countries with outward orientation has constituted the strongest argument in convincing policy makers elsewhere to adopt more open trade strategies. At the same time, some of the conventional wisdom about East Asia has come under attack. One line of argument, articulated most strongly by Wade (1990) and Amsden (1989), has taken neoclassical analysts of the East Asian miracle to task for failing to emphasize adequately the interventionist nature of East Asian strategies. In these accounts, exports and outward orientation are important, but so are the governments' consistent efforts to shape future comparative advantage through detailed industrial policies. In addition, recent work by Kim and Lau (1992) and Young $(1993,1994)$ has demonstrated that the growth of total factor productivity (TFP) in the East Asian tigers has not been superior to that in import-substituting countries in Latin America. Once factor accumulation (increases in physical and human capital and in labor-force participation rates) is taken into account, there is not much of a residual left over to attribute to TFP. Krugman (1994) has gone so far as to compare East Asia's accumulation-driven industrialization to the Soviet model. 
This paper is concerned with another part of the conventional wisdom, namely the view that the export booms in South Korea and Taiwan were in large part due to the change in relative prices in favor of exportables. While it is likely that policy reforms in both countries made exports more profitable in the 1960 s than they had been the decade before, it is also clear that the available data on relative prices reveal a number of anomalies. The actual increase in the relative profitability of exports in the 1960 s is small in both countries in relation to the phenomenal increase in exports. Moreover, the change in relative prices is by and large a onetime affair, with occasional reversals, while the export-GDP ratio increases continuously. These findings are put into sharper relief when we compare the East Asian export booms with those experienced elsewhere. As we shall see in the next section, more modest export booms in Turkey and Chile during the 1980 s have required cumulative real exchange-rate depreciations contemporaneously of the order of 100 percent, a change in relative prices vastly in excess of anything observed in East Asia. The question, therefore, is how South Korea and Taiwan were able to achieve such miraculuous export performance with so little change in relative prices.

A second puzzle has to do with investment. In both South Korea and Taiwan, the export booms were accompanied by investment booms that are equally impressive. Indeed, this investment performance is the proximate determinant of their economic growth. Nothing in theory or in the experience of other countries suggests that exports would necessarily pull investment up. In the factor-endowments model of trade, for example, an increase in openness is associated with a decrease in the retum to the scarce factor, capital in this case for both countries. Also, the experiences of Turkey and Chile, once again, are instructive. In neither country has the increase in exports been clearly linked with superior investment performance. The second question, then, is what made the East Asian experience special in this respect? I suggest in this paper that the two puzzles may have the same explanation. In particular, I will argue that export orientation in South Korea and Taiwan may have been the product in large 
part of an increase in the propensity to invest, brought about by a rise in the profitability of investment. This would explain why the export booms took place despite relatively mild changes in relative prices of tradables. It would also explain the joint booms in exports and investment. This is in contrast to the export booms we have observed in the 1980 s in countries like Chile and Turkey, where exports have responded primarily to relative-price changes in their favor.

Why should an increase in the profitability of investment be associated with a rise in exports? In an economy like South Korea's or Taiwan's in the 1960s, the domestic capital-goods industry is poorly developed. Capital goods are mostly imported. Consequently an increase in investment becomes possible only through an increase in imports. But if the economy cannot borrow freely from abroad, an increase in exports is required to pay for the imports. What is the mechanism that in turn allows the export supply to increase? This could be an exogenous increase in the saving rate, or a change in intertemporal relative prices which induces businesses and households to save more. In either case, an increase in savings that matches the increase in desired investment will result in both imports and exports increasing. The key point is that the relative price of exportables need not change much for this scenario to obtain.

I will lay out a formal model in section III to discuss the analytics of this story in greater detail, and to compare export booms that arise from government policies that increase the relative price of exportables with those that arise from an increase in the relative profitability of investment. But to motivate the distinction more clearly, I begin with a brief comparison of the experiences of South Korea and Taiwan, on the one hand, and Chile and Turkey, on the other (section II). In section IV, I will discuss the empinical implications of the model further and speculate about the reasons why the profitability of investment may have risen in East Asia in the early 1960 s. 


\section{Contrasting Patterns of Export Booms}

(a) Korea and Taiwan. In South Korea and Taiwan, exports began to rise sharply some time during the early- to mid-1960s. It has become commonplace to link this performance with the outward-oriented reforms undertaken by the two governments. However, a closer look at the evidence reveals some puzzles. In both countries, most of the important export incentives had already been put in place several years before the export boom started. Once the boom got under way, it picked up speed even though the measured profitability of exports did not increase further. Moreover, exports continued their rise often in the context of deteriorating incentives for exporting activities.

Figure 1 shows the case of South Korea. In this case, we are lucky to have detailed studies of the price effects of the various export incentives employed by Korean governments. Hence the relative-price series shown in the figure is the real (WPI-deflated) effective exchange rate for Korean exports, a measure of the real exchange rate which includes the monetary equivalent of all the subsidies on exports--export premia through the import link, cash grants, tax incentives, duty-free imports, export credits and the like. This is therefore an appropriate index of the profitability of exporting relative to other activities in the Korean economy. Also shown is the export-GNP ratio.

There were a number of export incentives in Korea prior to 1958. Most notably, exporters could retain a share of their export eamings to import certain items for home consumption, a system which translated into a large export subsidy whenever the free-market exchange diverged greatly from the offical rate. After 1958, the scope of incentives was substantially increased. Exporters were given taniff exemption on imports of raw materials and spare parts and gained access to subsidized credit in 1959. There were devaluations in 1961 and 1964, which

'The relevant studies are Kim (1988) and Frank et al. (1975). These are the most authoritative and widely cited sources on the quantitative aspects of Korea's trade regime. 
eliminated the gap between official and parallel exchange rates.

Figure 1 shows that even with the devaluation of 1964 the level of export incentives in 1964-65 was no more than 10 percent higher than in the preceding couple of years, and actually below the level attained in 1959-60. Even though exports rose very fast from 1964 onward, they were not to regain their 1959-60 level of profitability until the early 1970 s, and then again only briefly. By the mid-1970s, the export-GDP ratio was nearly ten times larger than in the early 1960s, yet the relative profitability of exports was lowerl Hence it seems clear that the greatest impact of the incentives was felt around 1959-60, rather than in the mid-1960s. This was due to two reasons: (i) the export subsidy implicit in the export-import link system was particularly significant in 1959-60 when the gap between the official and parallel exchange rates was large; and (ii) inflation eroded many of the export incentives between 1961 and 1964 . The devaluation of 1964 and the widening scope of export subsidies could offset the deterioration of incentives since 1960 only partially. In any case, the Korean export spurt was not associated with a significant increase in the relative profitability of exports. ${ }^{2}$

The Taiwanese story is quite similar. Most of the export incentives in Taiwan were put in place in the mid- to late-1950s, even earlier than in Korea, and the currency was unified during 1958-61. By 1954-55, the system of import duty and commodity tax rebates for exportable production had already been implemented. In 1956, manufacturers were allowed to retain up to 80 percent of foreign exchange they earned from exports and use it for their own import needs. This ratio was raised to 100 percent of export earnings for most items after the exchange-rate reform of 1958. In 1957 a relatively generous export credit program was started (Hong, 1993, 345-46; Lin, 1973, 74-78 and $97 \mathrm{ff}$.). By July 1960, the difference between the official exchange rate and the market price of foreign currency had become insignificant.

\footnotetext{
${ }^{2}$ This has been noted by others. In their authoritative study of Korean development, Mason et al. explicitly state that "the industrial policy changes that took place in the first half of the 1960 s did not clearly result in a significant increase in the measurable incentive to export" $(1980,135)$. The same point is noted by Jones and Sakong (1980) as well.
} 
Since we do not have a composite measure of an effective exchange rate for exporters in Taiwan, we have to make do with a simple real exchange rate index, which is shown in Figure 2. However, as all the significant export subsidies had already been deployed by the late 1950s, the figure should give us a fairly accurate idea of the trend in the relative profitability of exports since 1960. We can see that the initial export spurt in 1963-64 was actually associated with a decrease in export incentives, indicated by a real appreciation of around 10 percent (the result of a fixed exchange rate). After 1964, the relative profitability of exports increased steadily until 1973. But it was not until 1969 that the export-GDP ratio resumed its climb. By the early 1980 s, the relative profitability of exports stood roughly at its level of 1961, yet the export-GDP ratio was more than four times as large.

Could the export boom of the 1960s have been a delayed response to the shift in incentives toards exports during the late 1950 s in both countries? Comparative evidence indicates that exports tend to react quite quickly to changes in incentives. To see this, we consider two of the most notable export booms outside of the East Asian region: those in Turkey and Chile during the 1980s.

(b) Turkey and Chile. The Turkish policy reforms in 1980 are perhaps the most reminiscent of the South Korean and Taiwanese ones enacted two decades earlier, at least in appearance. The trade-related component of the 1980 program included a large devaluation and a significant increase in export incentives (including tax rebates and subsidized credit). As in Korea and Taiwan, import liberalization was mild, and did not take place in eamest until after exports were booming. Chile, on the other hand, had already accomplished significant trade liberalization during the second half of the 1970s. Its trade regime consisted of a uniform tariff with practically no quantitative restrictions. However, export performance was hampered by an exchange rate that was allowed to become overvalued in the late 1970 s and early 1980 s. Once exchange-rate policy changed in the aftermath of the debt crisis, and a real depreciation was 
achieved, exports started to take off.

Figures 3 and 4 show that in both Turkey and Chile there is an unmistakable association between the real exchange rate and export performance. The export booms of the $1980 \mathrm{~s}$ coincide with sizable real depreciations (of the order of 100 percent) achieved cumulatively during the same period. Moreover, exports clearly suffered during periods of real appreciations (in the late 1970 s and the late 1980 s in both cases). These pictures reveal a very different relationship between the real exchange rate and exports compared to the previous figures on South Korea and Taiwan.

These visual impressions are confirmed by more formal statistical analysis. Table 1 displays the results of regressing two indicators of trade performance for these countries on three independent variables: the real exchange rate, the fiscal deficit as a share of GNP, and time. The two indicators of trade used are the export-GNP ratio and the Summers-Heston measure of total trade (exports plus imports) divided by GDP. (The Summers Heston measure is useful because it is in principle unaffected by valuation changes arising from movements in the relative prices of tradables over time.) The fiscal deficit is used as a proxy for aggregate demand, and it is expected to be negatively correlated with exports. The regressions reveal that even when one controls for the deficit and a time trend, the relationship between the real exchange rate and exports is both statistically and economically significant in the cases of Turkey and Chile. In Korea and Taiwan, on the other hand, we find no statistically significant relationship between the real exchange rate and exports, once a time trend is included. The results are similar with the total trade measure.

The experiences of these two groups of countries differ in another important respect. In both Korea and Taiwan, the export booms took place alongside booms in investment (Figures 5 and 6). Indeed it is these "miracles of accumulation" that account for the phenomenal growth rates experienced by these two countries. In Turkey and Chile, on the other hand, the 
association between exports and investment has been much weaker (Figures 7 and 8 ). In Turkey, the steady increase in exports in the early 1980 s took place in the absence of any significant investment response. An investment boom in the mid-1970s, meanwhile, had been accompanied by a reduction in the exports-GNP ratio. In Chile, there was some increase in investment after 1983, but this increase has been modest relative to the export performance and in comparison with the Korean and Taiwanese experiences in the 1960s.

(c) A Reconciliation. To understand the somewhat anomalous experience of South Korea and Taiwan in the 1960s it may help to shift our focus away from trade strategy to investment proper. Hence consider an (exogenous) increase in the profitability of investment, followed by an increase in the share of investment in GDP. Suppose that the country in question (like Korea and Taiwan during the $1960 \mathrm{~s}$ ) has a comparative disadvantage in producing capital goods. The investment boom will require a commensurate increase in imports (also as a share of GDP). And if international borrowing is restricted, exports must rise (as a share of GDP) to pay for the imports. For exports to increase in turn, there must be an increase in domestic saving matching the increase in investment demand. Provided savings does increase, then, we will observe an increasing trade orientation alongside the boom in investment. Note that this story reverses the causality between growth and exports. Export orientation enables growth (by allowing imports to increase), but it is not its ultimate determinant. Ultimately, the reasons for growth must be traced back to reasons why it became profitable to invest. ${ }^{3}$

The scenario laid out above is consistent with the Korean and Taiwanese experiences. First, a casual look at the data shows that in both cases investment and imports are closely related. As Figures 9 and 10 make clear, the behavior of imports tracks quite closely the behavior of investment. In Korea, investment and imports both rise (as a share of GDP) until around 1980, and then stabilize somewhat. In Taiwan, investment and imports rise in tandem

\footnotetext{
${ }^{3}$ Bradford (1990) also suggests that investment may have played a causal role in export performance.
} 
until the late 1970s, and then both decline somewhat. Figures 11 and 12, showing the composition of imports, make clear the connection. Since the mid-1960s the share of capital goods (machinery and transport equipment) in both countries' imports has risen sharply. In fact, it is mainly the increase in capital goods that accounts for the rise in the imports-GDP ratio.

Table 2 reports the results of two-way Granger causality tests between investment and openness in our four countries. While the economics of the story outlined above does not suggest temporal leads and lags which Granger causality tests can pick up, the results are interesting nonetheless. In both Korea and Taiwan there is evidence that investment has Granger-caused trade, while in Chile and Turkey there is no such evidence. (Note that in Taiwan's case there is evidence of reverse causality from trade to investment as well.) Hence, in principle the increasing export orientation of the East Asian economies is consistent with investment-led growth, with causality running from investment to imports and from imports to exports. The evidence is broadly consistent with this scenario. In the next section, I lay out a formal model to develop the argument in greater detail.

\section{A General-Equilibrium Model}

We need a well-articulated model to explore the implications of the two types of outward-oriented development paths discussed above. In the first of these, exports are spurred by exportpromotion policies, or by the reduction of anti-export bias. In the second, an investment boom increases demand for imported capital goods, which in turn leads to increased export supply to pay for the imports. The logic of the first story is fairly clear. But the second requires an explicit model to understand how, if at all, increased investment demand translates into increased exports. In addition, since the contrasting behavior of real exchange rates in different countries is the empinical motivation of this paper, we would like to know the conditions under which the second scenario yields no significant depreciation of the real exchange rate. 
Since investment behavior is part of the second scenario, we need a model with at least minimal intertemporal dynamics. I will take the simplest such model, one with two periods. The first period, on which the analysis will focus, is associated with the short run, and the second period with the long run. Investment is undertaken only in the first period, as the second period is the terminal one. In addition, we need at least two goods in the first period to be able to talk about relative prices within that period. I assume that the economy produces and consumes two goods in the first period: an exportable and a non-traded good. There is also a third good, which is a capital good, and it is imported since it is not produced at home. A single (tradable) good is consumed and produced in the second period.

Normalize the world prices of all consumption goods to unity, and let $p$ stand for the price of the non-traded good. When there is a subsidy on exports in the first period, the domestic price of the exportable becomes $1+s$. Further, let $r$ be the real interest rate in terms of tradables, and $\delta$ the corresponding discount factor $(\delta=1 /[1+r])$. There are three relative prices in this model: the relative price of exportables to importables, $(1+s) / q$, the intertemporal relative price $\delta$, and

$$
\pi \equiv \frac{1+s}{p}
$$

which I will call the real exchange rate.

We can capture consumer behavior with the expenditure function $E(1+s, p, \delta, W)$, which gives the minimized present discounted value of consumption expenditures needed to attain utility level $W$. Note that the discounted price of the second-period good is simply $\delta$. This expenditure function has all the normal properties, including homogeneity of degree one in all prices. Letting a subscript denote a partial derivative with respect to the relevant variable, $E_{i}($.$) is$ the compensated demand for the ith good. Compensated demand curves slope downwards, so $E_{i i}()<$.0 . Finally, we assume that all three goods are compensated substitutes, so that $E_{12}($. 
0 and $E_{23}() \geq$.0 .

Producers' behavior is captured in turn with revenue functions of the form $R^{1}(1+s, p, K)$ and $R^{2}(1, K+1, \theta)$ for the first and second periods, respectively. These give the maximized value of GDP when producers face prices $1+s$ and $p$ (in the first period) and 1 (in the second period), and the economy's capital stock is fixed at $K$ (in the first period) and $K+l$ (in the second period). I have included a shift factor, $\theta$, in the second-period revenue function to allow for an exogenous increase in the productivity of capital: $R_{\theta}^{2}()>$.0 and $\left.R_{k f}^{2}.\right)>0$. The revenue function is homogeneous of degree one in prices, and its partial derivatives with respect to a price gives the supply of the relevant good. Further, $R^{1}{ }_{11}>0, R^{1}{ }_{22}>0$, and $R^{1}{ }_{12}<0$.

We take the economy's initial capital stock $K$ as given. Producers choose the investment level by maximizing the present discounted value of second period GDP net of present investment costs. Let $q$ stand for the world price of the capital good. Then their problem can be stated as follows:

$$
\max _{I} \delta R^{2}(1, K+l, \theta)-q l
$$

which yields:

$$
\delta R_{K}^{2}(1, K+l, \theta)=q
$$

This implicitly defines investment as a function of $\delta, q$, and $\theta$.

Suppose the export subsidy is financed by a lump-sum tax on the representative consumer, and let $x$ stand for first-period exports. The intertemporal resource balance constraint for the economy as a whole can be written as:

$$
E(1+s, p, \delta, W)+q I=R^{1}(1+s, p, K)+\delta R^{2}(1, K+l, \theta)-s x
$$


where the left-hand side is the present discounted value of total expenditures, including investment spending, and the right-hand side is the present discounted value of production revenue minus the tax. If the economy cannot freely borrow from or lend to the rest of the world, which we assume, realistically, to be the case, there will be analogous income-expenditure identities for each of the two periods separately. Without loss of generality, we fix the current account deficit in each period to zero. In view of (3), we need to state the budget constraint only for one of the two periods. It is easier to work with the one for the second period, which is given as follows:

$$
E_{3}(1+s, p, \delta, W)=R^{2}(1, K+l, \theta)
$$

Equilibrium in the market for the non-traded good requires equality between demand and supply:

$$
E_{2}(1+s, p, \delta, W)=R_{2}^{1}(1+s, p, K)
$$

The volume of exports in the first period is in turn given by:

$$
x=R_{1}^{1}(1+s, p, K)-E_{1}(1+s, p, \delta, W)
$$

which is the difference between domestic supply and demand of the traded good. Using (1) and (3) and the homogeneity properties of the expenditure and revenue functions, we can also express exports as

$$
x=q l
$$

which makes perfect sense since capital goods can only be imported, and trade balance requires that imports of the capital good be paid for by exports. A direct implication of (6) is that exports and investment will always move together in this model. 
There are six endogenous variables in this model: $\pi, W, p, l, \delta$, and $x$. They are determined by the six independent equations (1)-(6). We will solve this model for the case of an export-oriented policy ( $d s>0$ ) and then for the case of a shock that increases the profitability of investment $(d \theta>0)$. However, it helps in building intuition about the intertemporal effects to solve the model first without the non-tradable good. So we begin by doing that.

(a) The model without non-tradable goods. The simplified version of the model without the non-tradable good becomes:

$$
\begin{gathered}
\delta R_{K}^{2}(1, K+l, \theta)=q \\
E(1+s, \delta, W)+q l=R^{1}(1+s, K)+\delta R^{2}(1, K+l, \theta)-s x \\
E_{3}\left(1+s, \delta, W=R^{2}(1, K+l, \theta)\right. \\
x=R_{1}^{1}(1+s, K)-E_{1}(1+s, \delta, W
\end{gathered}
$$

These four equations solve for the four endogenous variables $W, 1, \delta$, and $x$. Since $s$ is a policy variable and $q$ is exogenous, we note that in this framework an export subsidy would directly alter the relative price of exportables to importables $(1+s) / q$, while an increase in $\theta$ would not. Hence it is clear that if an increase in the profitability of investment leads to an increase in investment, this will be accompanied by an equivalent increase in exports without any change in first-period relative prices.

To see how this works, we first differentiate the modified version of (3) setting $s=0$, and simplify to get:

$$
d W=\frac{\delta R_{\theta}^{2}}{E_{W}} \alpha \theta \equiv \Phi \alpha \theta>0, \quad \Phi>0
$$


where $E_{w}>0$ is the inverse of the marginal utility of income. This simply states that there is a positive income effect from an increase in the productivity parameter $\theta$. The values of $\delta$ and $I$ can then be jointly solved from the following system:

$$
\left[\begin{array}{ll}
R_{K}^{2} & \delta R_{K K}^{2} \\
E_{B \delta} & -R_{K}^{2}
\end{array}\right]\left[\begin{array}{l}
d \delta \\
d l
\end{array}\right]=\left[\begin{array}{c}
-\delta R_{K \theta}^{2} d \theta \\
R_{\theta}^{2}\left(E_{W}\right)^{-1} E_{1 W} \alpha \theta
\end{array}\right]
$$

where I have used the property that $E_{1 W}+\delta E_{o w}=E_{w}$. The determinant of the system is given by

$$
\mathrm{K}=-\left(R_{K}^{2}\right)^{2}-\delta E_{88} R_{K K}^{2}<0
$$

where I make use of the fact that $R_{k K}{ }^{2}<0$, i.e., the retum to capital is decreasing in the aggregate capital stock of the economy. The investment response can then be stated as follows:

$$
\frac{d l}{d \theta}=\frac{1}{K}\left[\delta E_{\delta 0} R_{k \theta}^{2}+R_{K}^{2} R_{\theta}^{2}\left(E_{W}\right)^{-1} E_{1 W}\right]
$$

There are two conflicting effects here. The first term captures the direct effect of the increase in the profitability of investment, and tends to push investment up. The second term captures a more subtle effect. Consumers would like to take some of the increase in their future income in the form of increased consumption in the present. But since they cannot borrow from abroad, this calls for an equilibriating reduction in $\delta$ (increase in the real interest rate). That in turn reduces the incentive to invest. Indeed the solution for $d 0$ is:

$$
\frac{d O}{d \theta}=\frac{\delta}{K}\left[R_{K}^{2} R_{K \theta}^{2}-R_{K K}^{2} R_{\theta}^{2}\left(E_{W}\right)^{-1} E_{1 W}\right]<0
$$

The net effect on investment (and first-period exports) will be positive as long as the equilibrium 
increase in the real interest rate is not too large.

(b) A policy that increases the relative profitability of exports. We now return to the full model and analyze the consequences of an export subsidy in greater detail. To simplify matters, I focus on the case of a "small" export subsidy, so that we can evaluate the comparative statics of the system at $s=0$. We take $\theta$ to be constant throughout this sub-section.

Differentiating (3) totally we are left with $d W=0$, after using (2) and setting $s=0$. This simply states that in an otherwise undistorted economy a small export subsidy has no first-order effect on real income. With income effects out of the way, we can then focus on substitution effects. From (2) we get:

$$
\frac{d l}{d \delta}=-\frac{R_{K}^{2}}{\delta R_{K K}^{2}} \equiv \Psi>0
$$

This equation shows that the investment response to the export subsidy depends solely on what happens to the real interest rate. The investment response is positive if the interest rate falls ( $\delta$ increases).

In view of (8) and the fact that $d W=0$, the comparative statics of equations (4) and (5) can be reduced to a two-dimensional system, which can be used to solve for the changes in $p$ and $\delta$. The system can be wrritten in matrix form as follows:

$$
\left[\begin{array}{cc}
E_{32} & E_{33}-R_{K}^{2} \Psi \\
E_{22}-R_{22}^{1} & E_{23}
\end{array}\right]\left[\begin{array}{l}
d p \\
d \sigma
\end{array}\right]=\left[\begin{array}{c}
-E_{31} d s \\
R_{21}^{1}-E_{21} d s
\end{array}\right]
$$

with the determinant

$$
\Delta \equiv\left(E_{32}\right)^{2}-\left(E_{22}-R_{22}^{1}\right)\left(E_{33}-R_{K}^{2} \Psi\right)<0
$$


A sufficient condition for the determinant to be negative is that own-price effects be stronger than cross-price effects (i.e., $\left.\left(E_{32}\right)^{2}-E_{22} E_{33}<0\right)$. I assume that this is indeed the case.

Using Cramer's rule, we can now derive the solutions:

$$
\begin{aligned}
& \frac{d D}{d s}=\frac{1}{\Delta}\left[E_{32}\left(R_{21}^{1}-E_{21}\right)+E_{31}\left(E_{22}-R_{22}^{1}\right)\right]>0 \\
& \frac{d p}{d s}=\frac{1}{\Delta}\left[-E_{31} E_{23}-\left(R_{21}^{1}-E_{21}\right)\left(E_{33}-R_{K}^{2} \Psi\right)\right]>0
\end{aligned}
$$

Hence, the effects of the subsidy on the discount factor and on the non-tradable price are unambiguous. The discount factor rises (the real interest rate falls) as a consequence of the intertemporal shift in expenditures towards the future. Since the export subsidy makes the exportable more expensive at home, consumers respond by switching demand towards other goods, including future goods. This results in an increase in the price of future goods, showing up as an increase in $\delta$. The price of the non-tradable $(p)$ increases for very much the same reason. The switch in domestic expenditures towards the non-tradable (as well as the reduction in its supply) puts upward pressure on $p$.

Remember that we are interested in this case mainly because we would like to use it as a benchmark for a companison with the consequences of an exogenous increase in the profitability of investment. We are particularly interested in the possibly contrasting behavior of the real exchange rate. At first sight, it might appear that the real-exchange-rate consequence of the export subsidy is ambiguous since both the numerator $(1+s)$ and the denominator $(p)$ increase with the subsidy. In fact, that is not right. For the real exchange rate to depreciate, we need

$$
0<\frac{d p / p}{d s}<1
$$


since $s=0$ initially. This requires

$$
-E_{31} E_{23}-\left(R_{21}^{1}-E_{21}\right)\left(E_{33}-R_{K}^{2} \Psi\right)>p\left(E_{32}\right)^{2}-P\left(E_{22}-R_{22}^{1}\right)\left(E_{33}-R_{K}^{2} \Psi\right)
$$

Rearranging terms:

$$
\left(E_{33}-R_{K}^{2} \Psi\right)\left[\left(\rho E_{22}+E_{21}\right)-\left(\rho R_{22}^{1}+R_{21}^{1}\right)\right]>E_{32}\left(\rho E_{32}+E_{31}\right)
$$

Now note that $R_{12}{ }^{1}+p R_{22}{ }^{1}=0, E_{21}+p E_{22}=-\delta E_{23}$, and $E_{31}+p E_{32}=-\delta E_{33}$. Consequently, the requirement simplifies to

$$
\delta R_{K}^{2} E_{23} \Psi>0
$$

This is unambiguously true provided there is some substitutability in consumption between the non-tradable good and future goods $\left(E_{23}>0\right)$. That is, the real exchange rate is guaranteed to depreciate under minimal conditions.

(c) An increase in the profitability of investment. We saw in the no-nontradables case that it is possible for investment and exports to increase without any change in relative prices within the first period. We now ask whether the same can obtain in the presence of nontradables. In particular, we are interested in the outcome for the real exchange rate.

As in part (a), the increase in $\theta$ results in a rise in utility, the expression for which is identical to that contained in (9). Differentiating (2), (4), and (5) and substituting from (9), we get:

$$
\left[\begin{array}{ccc}
R_{K}^{2} & \delta R_{K K}^{2} & 0 \\
E_{33} & -R_{K}^{2} & E_{32} \\
E_{23} & 0 & E_{22}-R_{22}^{1}
\end{array}\right]\left[\begin{array}{l}
\alpha \delta \\
d l \\
d p
\end{array}\right]=\left[\begin{array}{c}
-\delta R_{K \theta}^{2} \alpha \theta \\
R_{\theta}^{2}\left(E_{W}\right)^{-1}\left(E_{1 W}+p E_{2 W}\right) \alpha \theta \\
-E_{2 W} \Phi \omega \theta
\end{array}\right]
$$


The determinant of the system is given by

$$
\Omega=-\left(R_{K}^{2}\right)^{2}\left(E_{22}-R_{22}^{1}\right)+\delta R_{K K}^{2}\left(E_{32}\right)^{2}-\delta R_{K K}^{2} E_{33}\left(E_{22}-R_{22}^{1}\right)>0
$$

Since the middle term is negative, we again appeal to own-price effects to be stronger than cross-price effects in signing the determinant. With this result in hand, we can now carny out the comparative statics of the system.

We first check the conditions under which investment actually increases:

$$
\frac{d l}{d \theta}=\frac{1}{\Omega}\left[R_{K}^{2} R_{\theta}^{2} E_{w}^{-1}\left(E_{1 w}+\rho E_{2 w}\right)\left(E_{22}-R_{22}^{1}\right)-\delta R_{k \theta}^{2}\left(\left(E_{32}\right)^{2}-E_{33} E_{22}+E_{33} R_{22}^{1}\right)+E_{2 w} E_{23} R_{k}^{2}\right]
$$

The sign of this expression is ambiguous in general, as in the case without nontradables, and for the same reason (cf. eq. (12)). The income effect of the productivity increase (which arrives only in the second period) increases desired consumption in both periods, and pushes the real interest rate up to eliminate the excess demand in the first period. Investment may suffer as a result. Provided this effect is small, however, investment will increase.

Finally, we check the effect on the real exchange rate. Since $s$ is constant (at zero), the real exchange rate moves with the inverse of $p$. Again using Cramer's rule on (18) we have:

$$
\frac{d p}{d \theta}=\frac{1}{\Omega}\left[E_{2 W} \Phi\left(\delta E_{33} R_{K K}^{2}+\left(R_{K}^{2}\right)^{2}\right)+\delta E_{23}\left(R_{K K}^{2} R_{\theta}^{2} E_{W}^{-1}\left(E_{1 W}+p E_{2 W}\right)-R_{K}^{2} R_{K \theta}^{2}\right)\right]
$$

Unlike in the case of the export subsidy, the effect on the real exchange rate is now ambiguous. The first term in square brackets is positive, and tends to appreciate the real exchange rate. It is the consequence of the increased demand for the non-tradable as real income increases. This effect is stronger the larger is $E_{2 W}$. (Note that $E_{2 w}$ is the product of the inverse of the marginal 
utility of income and the income effect on demand for the non-tradable.) The second term in square brackets is negative, and tends to depreciate the real exchange rate. The operative channel here is the reduction in demand for the non-tradable as a consequence of the rise in the real interest rate. This second effect is smaller the smaller is $E_{23}$, which is the interest-rate sensitivity of non-tradables demand.

What this last result demonstrates is the possibility that investment and exports may both increase with very little change in the real exchange rate, when the process is set into motion by an increased profitability of investment. In an economy which is dependent on capital-goods imports, and is constrained in its extemal borrowing, an increase in investment demand results in an increase in export supply. The mechanism through which this happens is an increase in real interest rates which reduces present consumption. This effect on its own, however, also tends to reduce the price of non-tradables and depreciate the real exchange rate. A partly offsetting factor is that the income effect of the increase in profitability increases aggregate demand. This tends to reduce (or reverse) the real depreciation, but it also reduces exports.

To see how we can get an increase in exports with no change in the real exchange rate, consider a limit case: let the income elasticity of demand for non-tradables (exportables) be very large (zero), and the interest-rate elasticity of demand for non-tradables (exportables) be zero (very large). Then, the income effect appreciates the real exchange rate with little impact on exports, while the interest-rate effect increases exports with little impact on the real exchange rate. In general, the larger the income elasticity (and the smaller the interest-rate elasticity) of demand for non-tradables, the greater the likelihood that an increase in exports will be associated with little movement in the real exchange rate.

\section{Confronting the Model with Reality}

There are two issues raised by the model which require additional discussion. First, I have said 
nothing so far about the possible reasons for the increase in the profitability of investment in South Korea and Taiwan in the 1960s. What set this investment-led growth into motion? Second, an implication of the model is that the requisite increase in savings will require a change in the intertemporal structure of relative prices, an in particular an increase in the consumption rate of interest. Is there any evidence that anything of this kind took place, and were there other reasons (outside the model) that contributed to the rise in national savings? I take up these questions in order. ${ }^{4}$

(a) Profitability of investment. One of the most important changes that took place in the late 1950 s in Taiwan and the early 1960 s in Korea was a substantial transformation in government priorities. During much of the 1950 s, economic goals did not particularly rank high with either the Taiwanese or Korean leaderships. In Taiwan, the government was preoccupied with the reconquest of the mainland. In Korea, Syngman Rhee's attention was focussed on national consolidation and on political goals. Economic growth was not a priority in either country.

By the end of the decade, it became clear to the Taiwanese government that the communist regime was firmly entrenched. As Wade $(1990,246)$ puts it, "[Taiwan's] party elders came to see that economic development could be a better guarantee of the party's survival ...." An important turning point was the Nineteen-Point Reform Program instituted in 1960 . This contained a wide range of subsidies for investment, and signalled a major shift in government attitudes towards investment: as Lin $(1973,96)$ puts it, "[with] the announcement of the nineteenpoint reform program of 1960 , the improvement of investment climate became a catchword. The simplification of administrative procedures and the liberalization of regulative measures with regard to economic matters became an official goal." And in Korea, President Park, who took power in a military coup in 1961, could not have been more different from his predecessors.

\footnotetext{
${ }^{4}$ This section draws heavily on Rodrik (1995).
} 
Park gave precedence to economics over politics, and to economic growth over other economic concerns. These priorities were reflected in the amount of time he spent on economic matters and in his support of growth-oriented bureaucrats and businessmen (see Jones and Sakong, $1980,40-43)$. Park made very clear early on in his rule that entrepreneurs who undertook investments in line with his priorities would be richly rewarded (while others were penalized). Hence, in both countries there was a sharp improvement in the investment climate.

In addition to eliminating obstacles to investment, government policy highly subsidized investment. In Korea, the chief form of investment subsidy was the extension of credit to large business groups at negative real interest rates. Korean banks were nationalized after the military coup of 1961, and consequently the government obtained exclusive control over the allocation of investible funds in the economy. According to Jones and Sakong, "the general bank [lending] rate has typically been half of the curb-market rate; and second, the real bank rate has often been negative and generally below even the most conservative estimates of the opportunity cost of capital" (104). Another important manner in which investment was subsidized in Korea was through the socialization of investment risk in selected sectors. This came about because the government--most notably President Park himself--provided an implicit guarantee that the state would bail out those entrepreneurs investing in "desirable" activities if circumstances later threatened the profitability of these investments.

In Taiwan, investment subsidies took different forms. Real lending rates were generally positive and credit subsidies were much less important. The most important direct subsidies in Taiwan came in the form of tax incentives. The Statute for Encouragement of Investment (enacted in 1960 in conjunction with the nineteen-point program mentioned above) represented a "sweeping extension" (Lin, 1973, 85) of the prevailing tax credit system for investment. The maximum business income tax paid by enterprises was reduced to 18 percent of annual income (from a previous maximum of 32.5 percent); the tax holiday for new investments was extended 
from 3 to 5 years; tax exemption was given to undistributed dividends for reinvestment, 2 percent of FX earnings, and proceeds of export sales; the stamp tax and deed tax on "productive" real estate were made either tax exempt or taxable at reduced rates; payments of import duties on plant equipment were made deferrable, and payable in installments after starting operations. These incentives were further expanded in 1965, at which time the business income tax was reduced in all prionity sectors listed in the investment law, and specified manufacturing sectors (in basic metals, electrical machinery and electronics, machinery, transportation equipment, chemical fertilizers, petrochemicals, and natural gas pipe) were given complete exemption from import duties on plant equipment. ${ }^{5}$

In addition to providing subsidies, the Korean and Taiwanese governments played a much more direct, hands-on role by organizing private entrepreneurs into investments that they may not have otherwise made. In both cases, we have good case histories of how the government actively took steps to ensure that private entrepreneurs would invest in certain areas. In Taiwan, it was the government that took the initial steps in establishing such industries as plastics, textiles, fibers, steel, and electronics. In Korea, in the words of Amsden, "[t]he initiative to enter new manufacturing branches has come primarily from the public sphere. Ignoring the 1950s, ..., every major shift in industrial diversification in the decades of the 1960 s and 1970 s was instigated by the state...." (1989, 80-81).

Finally, public enterprises played a very important role in enhancing the profitability of private investment in both countries (perhaps more so in Taiwan than in Korea). They did so by ensuring that key inputs were available locally for private producers downstream. In Taiwan, it was common for the state to establish new upstream industries and then either hand the factories over to selected private entrepreneurs (as happened in the case of glass, plastics, steel, and cement) or run them as public enterprises (Wade, 1990, 78). In Korea, the

\footnotetext{
${ }^{5}$ The information in this paragraph is taken from Lin, 1973, 85-87 and Kuo, 1983, 301.
} 
government established many new public enterprises in the 1960s and 1970s, particularly in basic industries characterized by high degree of linkages and scale economies (Jones and Sakong, 1980). In both countries, public enterprises were the recipient of favorable credit terms, as well as direct allocations from the government budget. Not only did public enterprises account for a large share of manufacturing output and investment in each country, their importance actually increased during the critical take-off years of the 1960 s.

In an economy with complete markets, investment subsidies of the kind just discussed will reduce real income, even if they end up increasing investment. But of course this hardly applies to Taiwan and Korea in the 1960s. The more realistic starting point is that a range of market failures kept investment below what would have been socially optimal. I have argued elsewhere (Rodrik 1994, 1995) that there is a prima facie case for the existence of coordination failures in private-sector investment decisions in economies like Korea's and Taiwan's. This failure accounts for why large-scale investments would turn out to be privately (and socially) profitable while individual investments were perceived as not being profitable in the absence of government inducements. One way of viewing investment subsidies in these economies, then, is as policies that alleviated such coordination failures.

(b) Saving behavior. The model discussed in the previous section points to the key role played by the real rate of interest in enabling the increase in investment and exports. The latter requires a rise in savings, and in the model this is achieved through a rise in the real interest rate. In Korea and Taiwan, interest rates were controlled by the government, and in any case the bulk of investment funds were generated either through self-finance or through directed lending from the government. However, governments in both countries did raise real interest rates for savers to levels that were either positive or only mildly negative (Taiwan in the 1950s and Korea in the 1960s). In this respect, their policies diverged significantly from the gross financial repression favored by other developing-country governments (World Bank, 1993, 205-207). 
In addition, an increase in public savings made an important contribution to total savings in both countries. In Taiwan, the increase in the savings rate in the early 1960 s coincided with a sharp increase in government saving after 1961 (see Kuo 1983, pp. 8-9). This was enabled in turn by a reduction in government consumption. And in Korea, "it was the rapidly increasing contribution of government savings and the steady inflow of foreign savings which enabled Korea to achieve the very high rate of investment during the $1962-73$ period" (Hong, 1976, 19-20). The import of public savings in this context is that the improvement in government budgets added to national savings and obviated the need for a sharp change in intertemporal relative prices.

\section{Concluding Remarks}

What I have suggested in this paper is that an investment-based explanation may hold more promise in uncovering the secrets of the East Asian "miracles" than the trade-based explanations that are currently in vogue. In view of the phenomenal increase in Korea's and Taiwan's exports, the term "outward-oriented growth" is certainly accurate in a descriptive sense. However, there are problems when the term is used in a manner that implies causality. As I have argued, it is at least plausible that outward orientation was the consequence--rather than the cause--of an increase in investment demand. Consequently, what we need to understand better is the reasons behind these investment booms.

This perspective is also important in carrying the lessons of East Asia to other developing countries. Too often, a reform of trade strategy ("outward orientation") is portrayed as the key to fostering investment and growth. But what Korea's and Taiwan's experience really shows is that having a trade strategy is not enough. Governments may need an investment strategy as well. 


\section{REFERENCES}

Amsden, Alice H., 1989, Asia's Next Giant: South Korea and Late Industrialization, New York, Oxford University Press.

Bradford, Colin I., Jr., 1990, "Policy Interventions and Markets: Development Strategy Typologies and Policy Options," in G. Gereffi and D.L. Wyman, eds., Manufacturing Miracles: Paths of Industrialization in Latin America and East Asia, Princeton University Press, Princeton, NJ.

Frank, Charles R., Jr., Kwang Suk Kim, and Larry Westphal, 1975, Foreign Trade Regimes and Economic Development: South Korea, Columbia University Press, New York.

Hong, Wontack, 1976, Factor Supply and Factor Intensity of Trade in Korea, Korea Development Institute, Seoul.

Jones, Leroy, and II Sakong, 1980, Government, Business, and Entrepreneurship in Economic Development: The Korean Case, Harvard University Press, Cambridge, MA.

Kim, Jong-II, and Lawrence J. Lau, 1992, "The Source of Economic Growth of the Newly?. Industrialized Countries on the Pacific Rim," unpublished manuscript, Stanford University, December.

Kim, Kwang Suk, 1988, "The Timing and Sequencing of Trade Liberalization Policy: The Case of Korea," unpublished manuscript, World Bank.

Krugman, Paul, 1994, "The Myth of Asia's Miracle," Foreign Affairs, November-December, 62-78.

Kuo, Shirley, 1983, The Taiwan Economy in Transition, Westview Press, Boulder, Colorado.

Lin, Ching-yuan, 1973, Industrialization in Taiwan, 1946-72: Trade and Import-Substitution Policies for Developing Countries, Praeger, New York.

Mason, Edward S, and others, 1980, The Economic and Social Modernization of the Republic of Korea, Harvard University Press, Cambridge, MA.

Rodrik, Dani, 1994, "Coordination Failures and Government Policy in Intermediate Economies: A Model with Applications to East Asian and Eastern Europe," Columbia University (forthcoming Journal of International Economics).

Rodrik, Dani, 1995, "Getting Interventions Right: How South Korea and Taiwan Grew Rich," Economic Policy 20, April.

Wade, Robert, 1990, Governing the Market: Economic Theory and the Role of Government in East Asian Industrialization, Princeton, NJ, Princeton University Press.

World Bank, 1993, The East Asian Miracle: Economic Growth and Public Policy, Oxford University Press for the World Bank, Washington, DC.

Young, Alwyn, 1993, "Lessons from the East Asian NICs: A Contrarian View," NBER Working 
paper No. 4482.

Young, Alwyn, 1994, "The Tyranny of Numbers: Confronting the Statistical Realities of the East Asian Growth Experience,' unpublished paper, February. 


\begin{tabular}{|c|c|c|c|c|c|c|c|c|}
\hline & \multicolumn{2}{|c|}{ South Korea } & \multicolumn{2}{|c|}{ Taiwan } & \multicolumn{2}{|c|}{ Turkey } & \multicolumn{2}{|c|}{ Chile } \\
\hline Time Period & \multicolumn{2}{|c|}{$1956-1991$} & \multicolumn{2}{|c|}{$1960-1981$} & \multicolumn{2}{|c|}{$1967-1990$} & \multicolumn{2}{|c|}{$1960-1988$} \\
\hline r & X/GNP & $\begin{array}{c}(X+M) / G D P \\
\text { (Summers- } \\
\text { Heston) }\end{array}$ & X/GNP & $\begin{array}{c}(X+M) / G D P \\
\text { (Summers- } \\
\text { Heston) }\end{array}$ & XIGNP & $\begin{array}{c}(X+M) / G D P \\
\text { (Summers- } \\
\text { Heston) }\end{array}$ & XVGNP & $\begin{array}{c}(X+M) / G D P \\
\text { (Summers- } \\
\text { Heston) }\end{array}$ \\
\hline constant & $\begin{array}{c}-6.52 \\
(-0.15)\end{array}$ & $\begin{array}{r}6.21 \\
(0.05)\end{array}$ & $\begin{array}{l}-41.13 \\
(-8.86)\end{array}$ & $\begin{array}{c}-78.69 \\
(-11.49)\end{array}$ & $\begin{array}{c}-6.54 \\
(-3.89)\end{array}$ & $\begin{array}{l}-23.09 \\
(-3.87)\end{array}$ & $\begin{array}{c}4.49 \\
(0.47)\end{array}$ & $\begin{array}{c}7.18 \\
(2.15)\end{array}$ \\
\hline $\begin{array}{l}\log \text { of real } \\
\text { exchange rate }\end{array}$ & $\begin{array}{c}0.02 \\
(0.65)\end{array}$ & $\begin{array}{l}0.01 \\
(0.13)\end{array}$ & $\begin{array}{c}0.04 \\
(0.31)\end{array}$ & $\begin{array}{c}0.29 \\
(1.37)\end{array}$ & $\begin{array}{c}0.10 \\
(5.28)\end{array}$ & $\begin{array}{c}0.23 \\
(4.67)\end{array}$ & $\begin{array}{c}0.16 \\
(3.48)\end{array}$ & $\begin{array}{c}0.24 \\
(8.79)\end{array}$ \\
\hline $\begin{array}{l}\text { Fiscal } \\
\text { deficit/GNP }\end{array}$ & $\begin{array}{c}-0.17 \\
(-0.62)\end{array}$ & $\begin{array}{c}-0.14 \\
(-0.27)\end{array}$ & -- & - & $\begin{array}{c}0.12 \\
(0.81)\end{array}$ & $\begin{array}{c}0.40 \\
(1.35)\end{array}$ & $\begin{array}{c}-0.15 \\
(-0.65)\end{array}$ & $\begin{array}{c}-0.75 \\
(-5.88)\end{array}$ \\
\hline Time & $\begin{array}{c}0.00 \\
(0.16)\end{array}$ & $\begin{array}{l}-0.00 \\
(-0.05)\end{array}$ & $\begin{array}{c}0.02 \\
(8.55)\end{array}$ & $\begin{array}{c}0.04 \\
(10.94)\end{array}$ & $\begin{array}{l}0.00 \\
(3.56)\end{array}$ & $\begin{array}{c}0.01 \\
(3.71)\end{array}$ & $\begin{array}{c}-0.00 \\
(-0.53)\end{array}$ & $\begin{array}{c}-0.00 \\
(-2.29)\end{array}$ \\
\hline D.W. & $-A^{A}$ & $-A$ & $-{ }^{\mathbf{A}}$ & $--^{A}$ & $-A^{A}$ & $-A^{A}$ & $-A^{A}$ & 1.59 \\
\hline$A R(1)$ & $\begin{array}{c}0.96 \\
(9.25)\end{array}$ & $\begin{array}{l}0.96 \\
(9.39)\end{array}$ & $\begin{array}{c}0.51 \\
(2.18)\end{array}$ & $\begin{array}{c}0.53 \\
(2.09)\end{array}$ & $\begin{array}{c}0.44 \\
(2.35)\end{array}$ & $\begin{array}{c}0.67 \\
(3.61)\end{array}$ & $\begin{array}{c}0.73 \\
(2.66)\end{array}$ & -- \\
\hline $\bar{R}^{2}$ & 0.97 & 0.96 & 0.95 & 0.97 & 0.94 & 0.96 & 0.86 & 0.96 \\
\hline
\end{tabular}

Notes: t-statistics are in parentheses.

${ }^{A} A R(1)$ correction for serial correlation is used. Estimated $A R(1)$ coefficient is shown in next line.

${ }^{8}$ The real effective exchange rate (inclusive of export subsidies) used in the case of South Korea. 
Table 2: Granger Causality Tests on the Relationship Between Openness and Investment

\begin{tabular}{|c|c|c|}
\hline \multicolumn{3}{|c|}{ Openness does not cause Investment } \\
\hline & Accept & Reject \\
\hline Korea & $x$ & \\
\hline Taiwan & & $x^{*}$ \\
\hline Chile & $\mathbf{x}$ & \\
\hline Turkey & $\mathbf{x}$ & \\
\hline \multicolumn{3}{|c|}{ Investment does not cause openness } \\
\hline Korea & & $x^{* * *}$ \\
\hline Taiwan & & $x^{* *}$ \\
\hline Chile & $\mathbf{x}$ & \\
\hline Turkey & $x$ & \\
\hline
\end{tabular}

Notes: Annual data are used for the period 1950-92. The causality tests employ two lags. The variables are defined as follows: openness is the share of exports and imports in GDP and investment is the share of investment in GDP, all at international prices. The source for all data is the Heston-Summers data set (PWT 5.5). Levels of statistical significance are as follows:

* significant at the $1 \%$ level

** significant at the $5 \%$ level

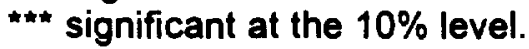


Real Effective Exchange Rate and Exports, Korea

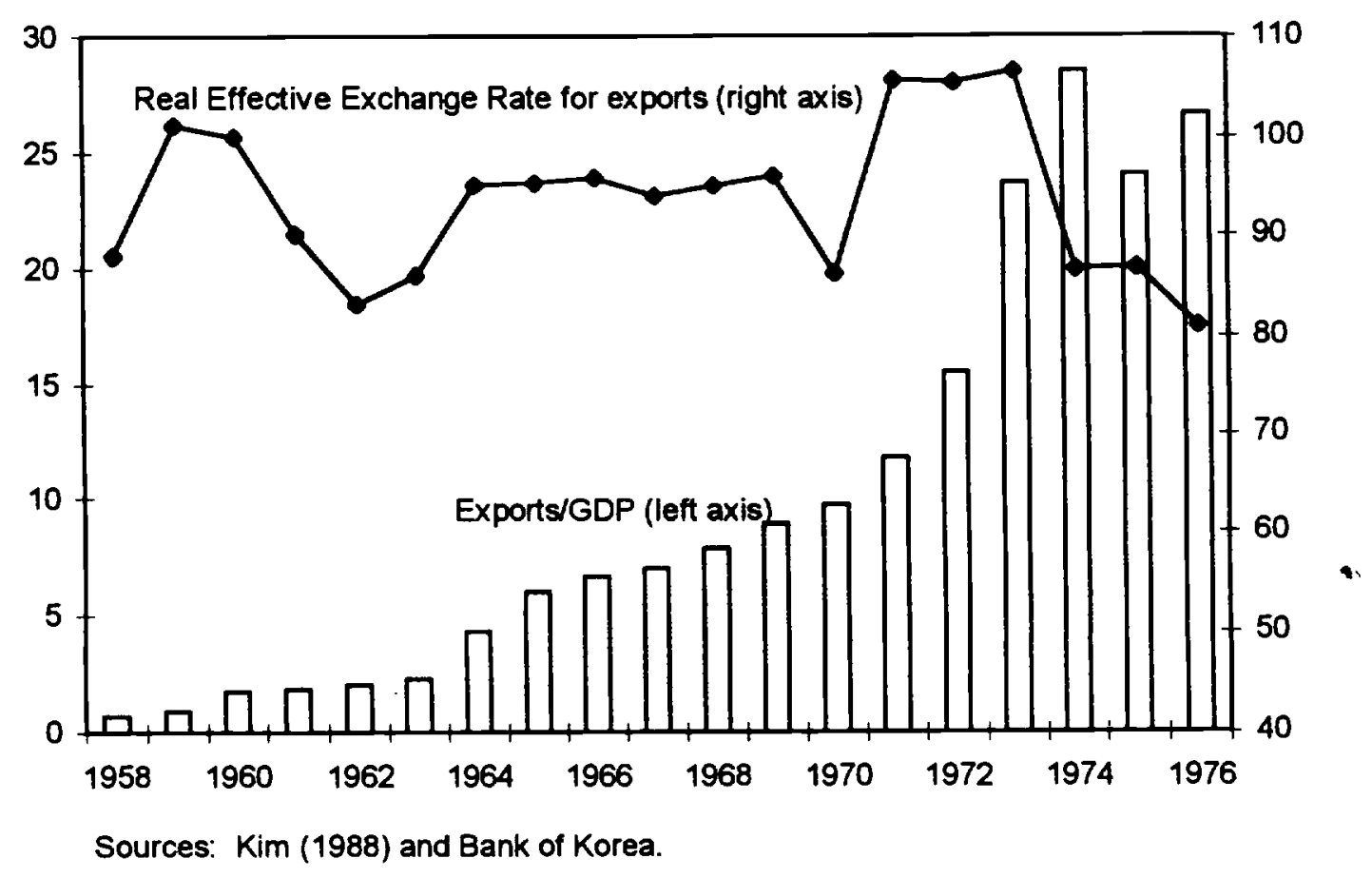

Figure 1 
Real Exchange Rates and Exports, Taiwan

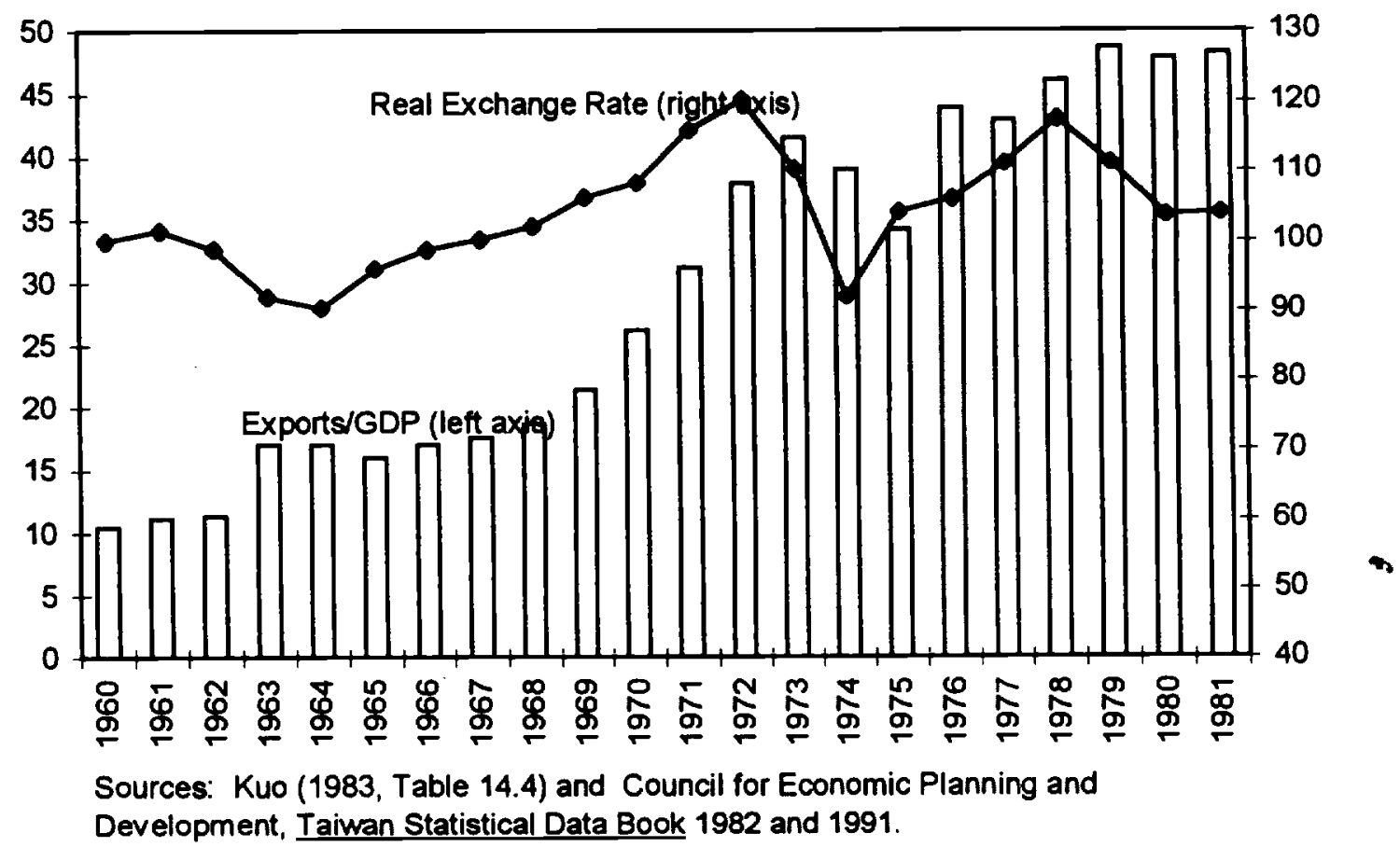

Figure 2 
$\frac{7}{9}$
ำ
$\omega$

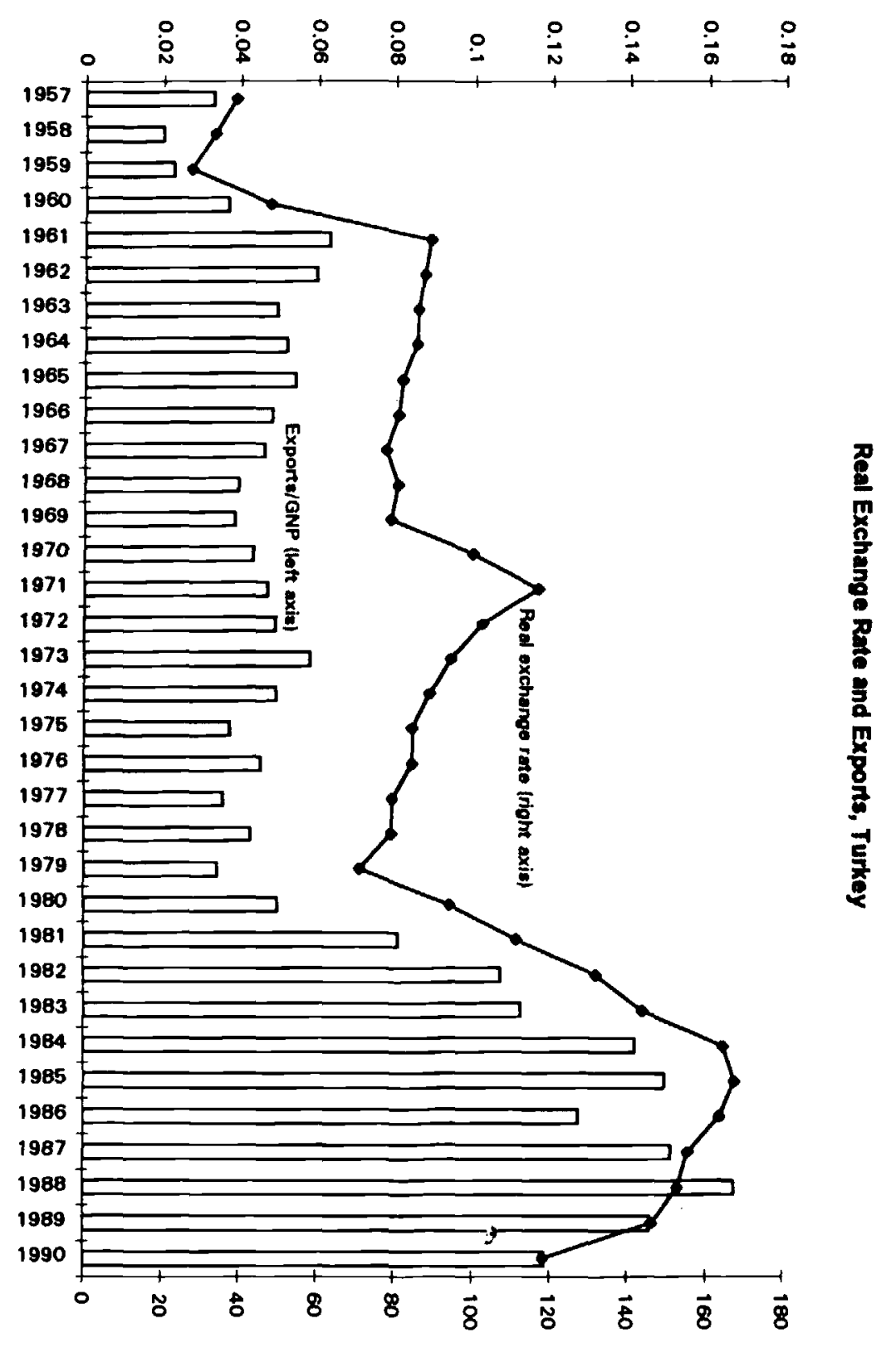




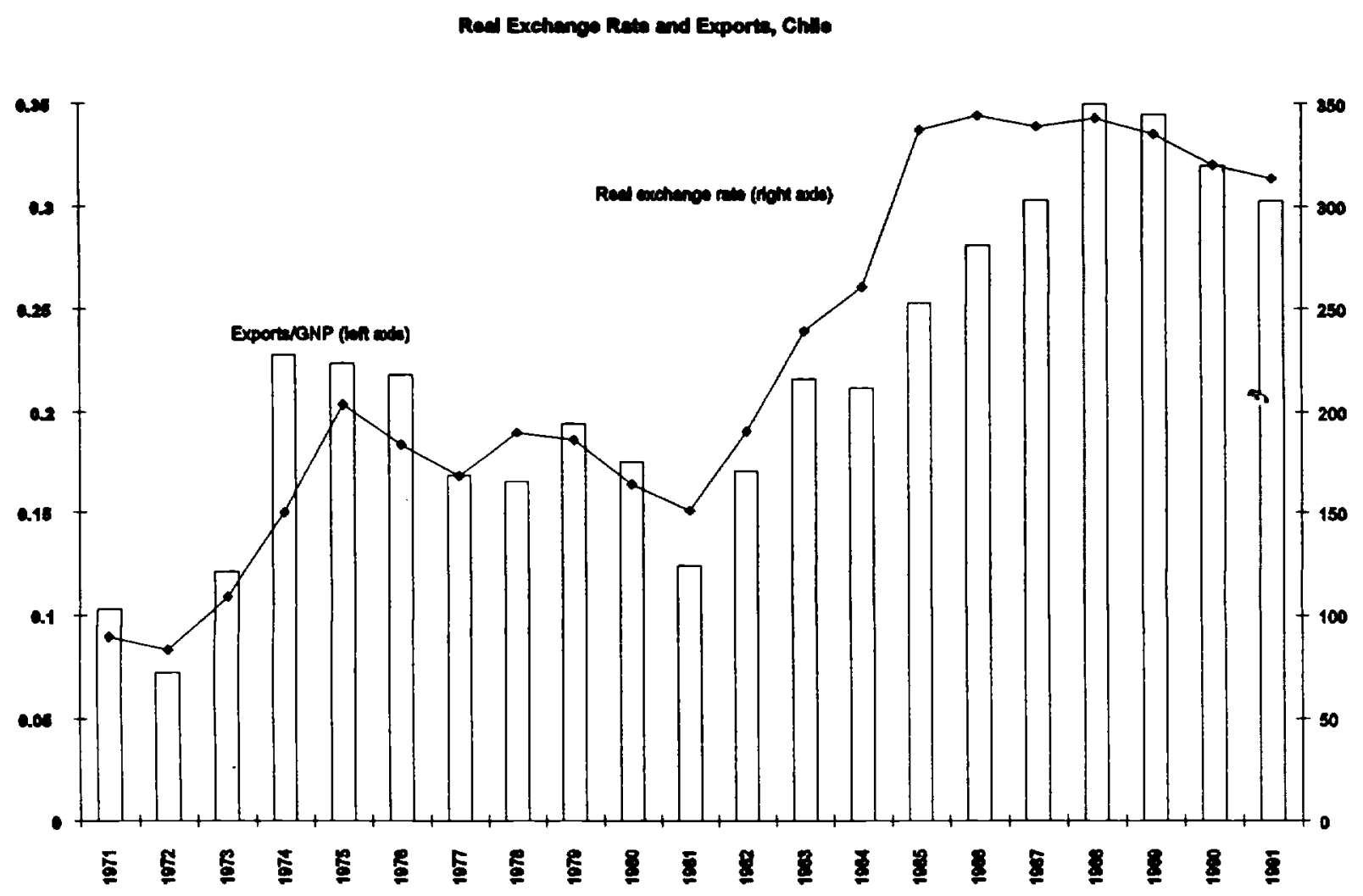

Figure 4 
ñ
ç
on

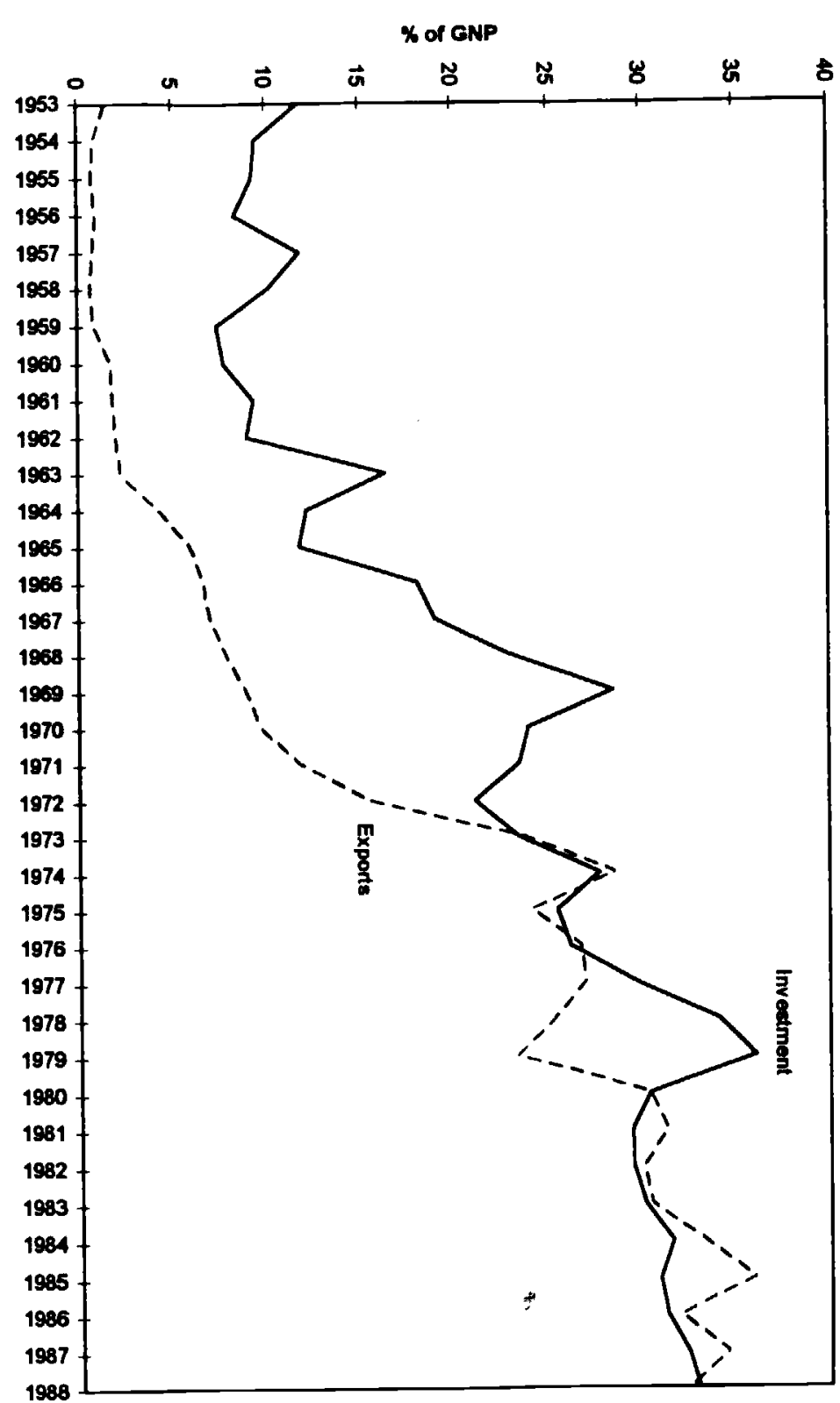

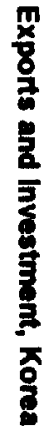




\section{Exports and Investment, Talwan}

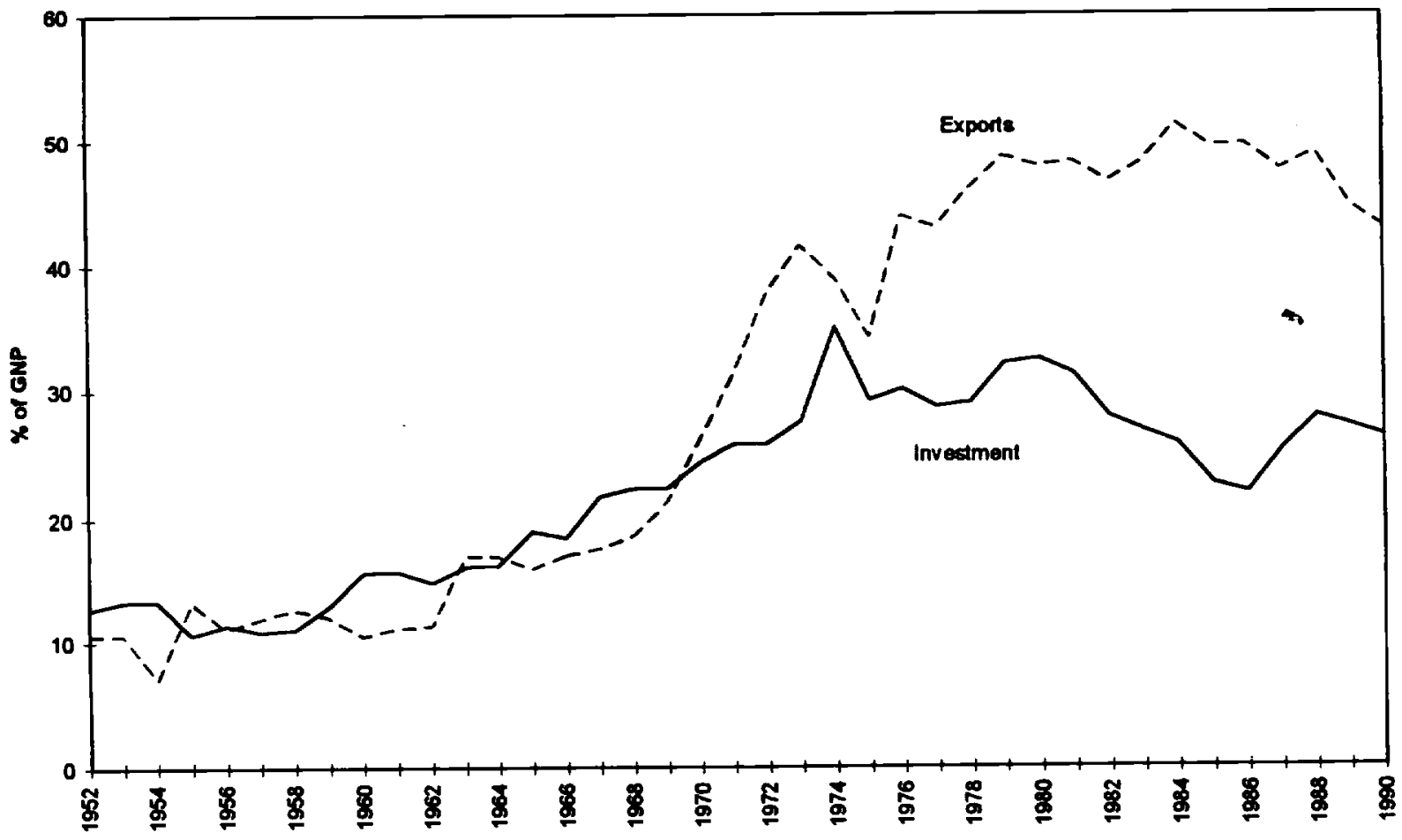

Figure 6 
Exports end lomeernent, Turkey

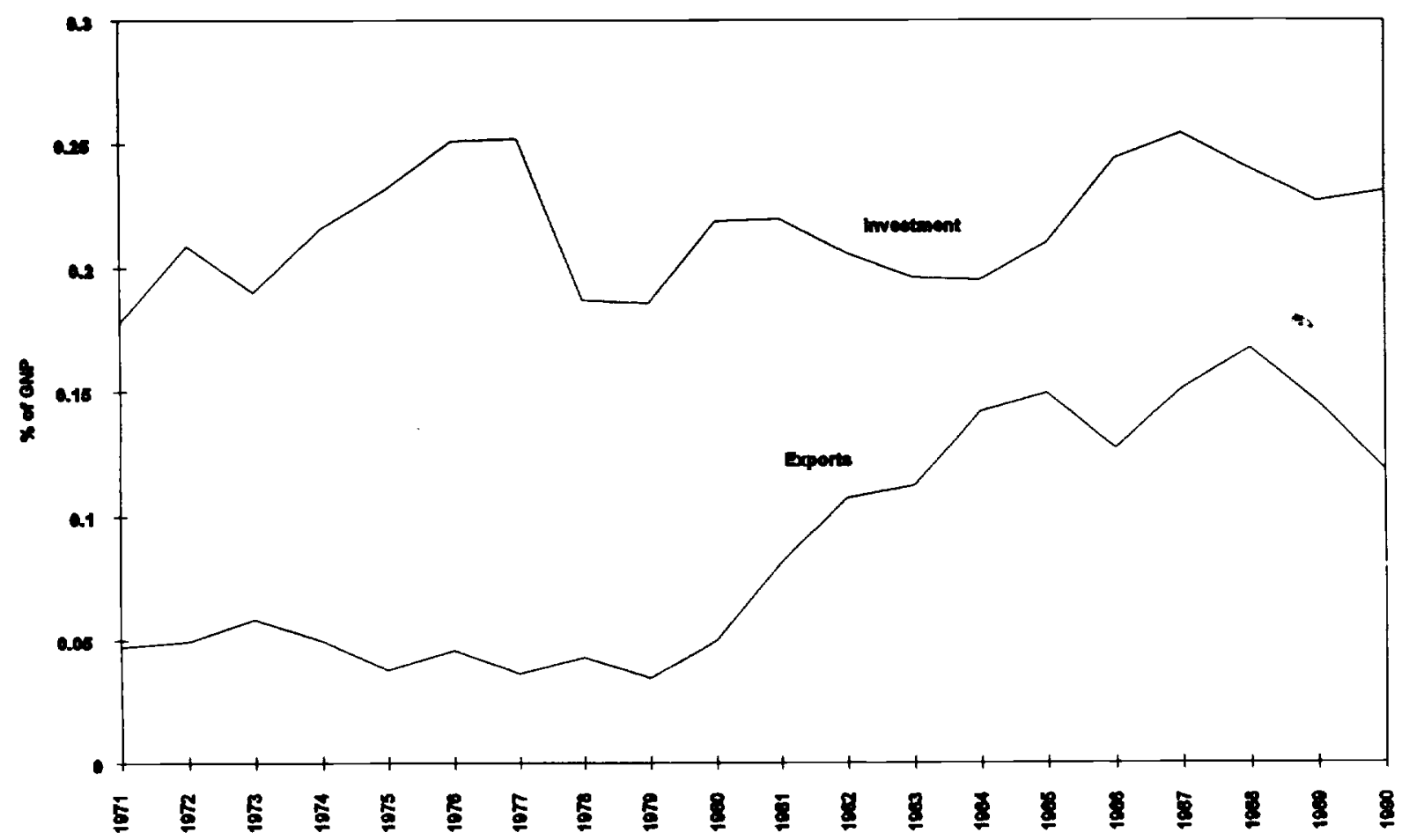

Figure 7 


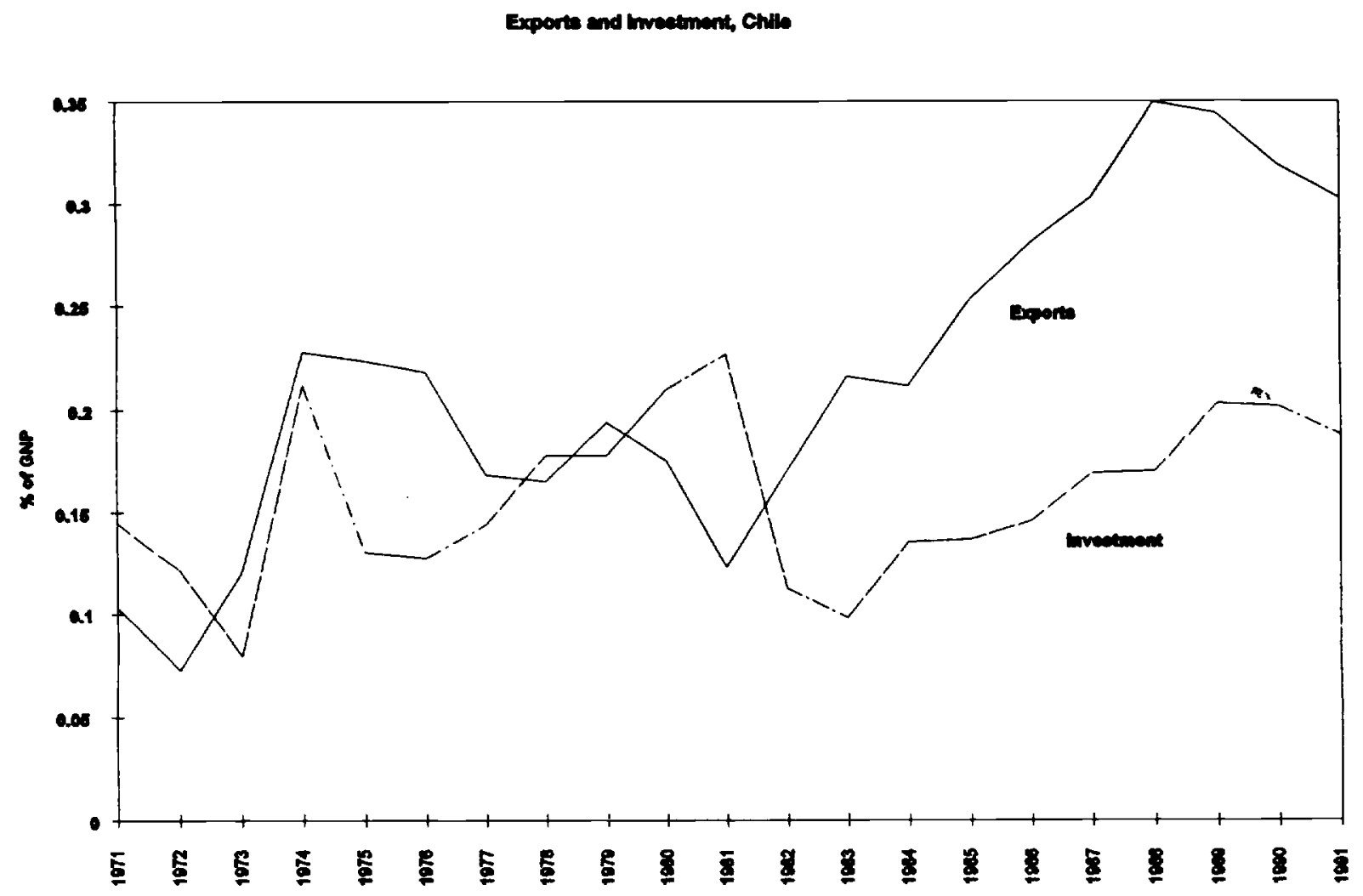

Figure 8 


\section{Imports and Investment, Korea}

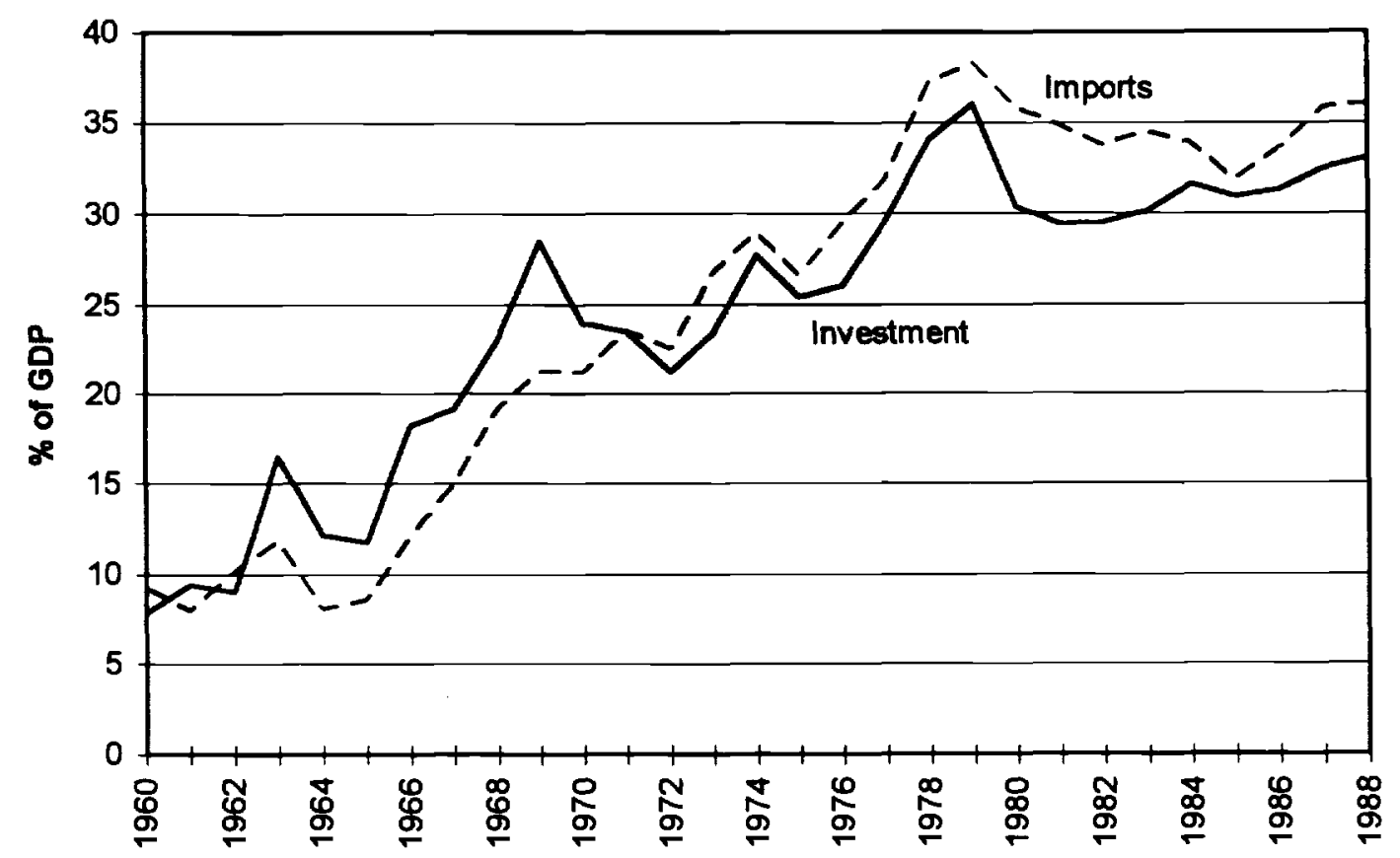

Source: Penn World Table 5.5 and Economic Planning Board, Major Statistics of the Korean Economy, various issues

Figure 9 
Imports and Investment, Taiwan

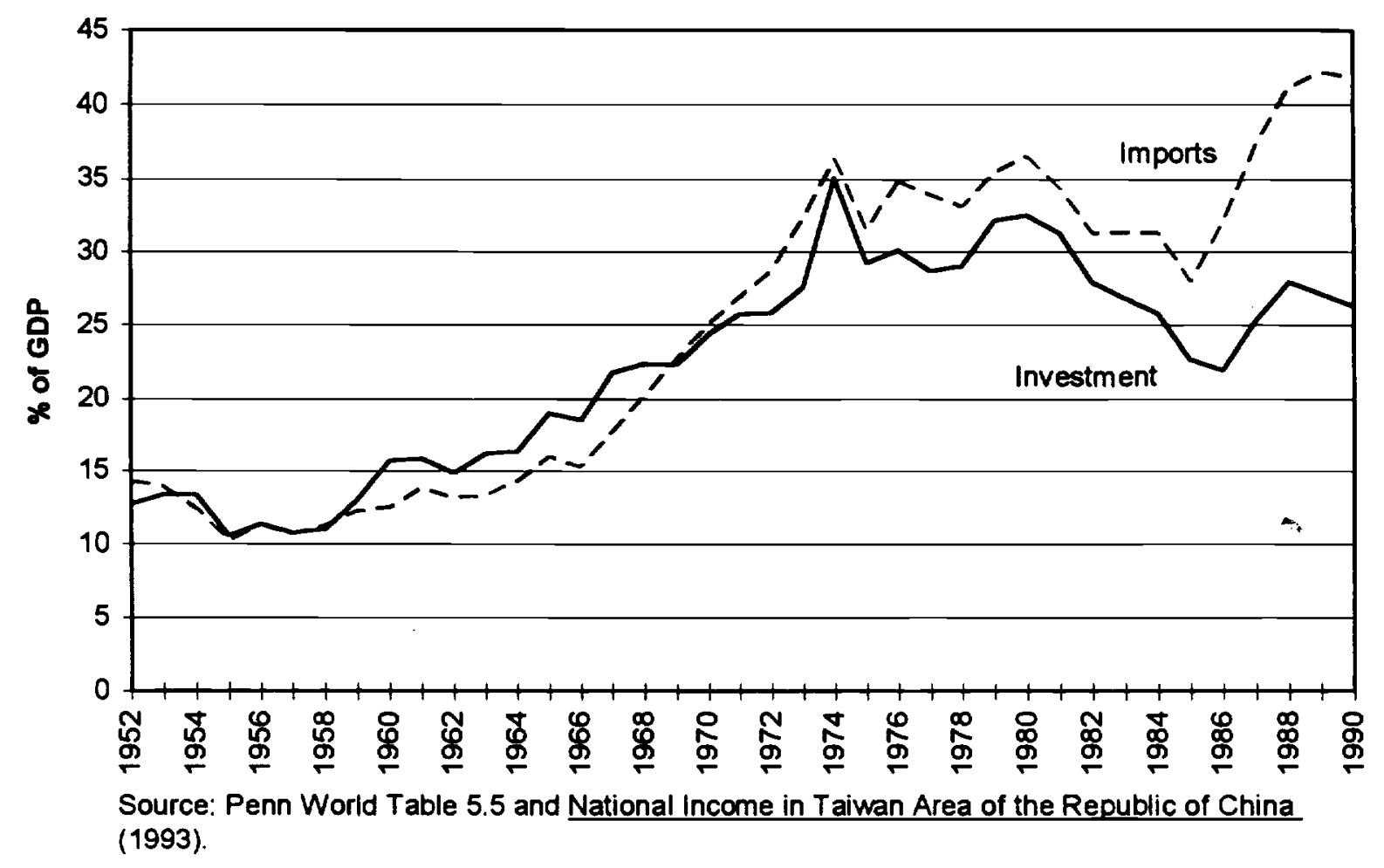

Figure 10 


\section{Korea: Imports as a Share of GDP}

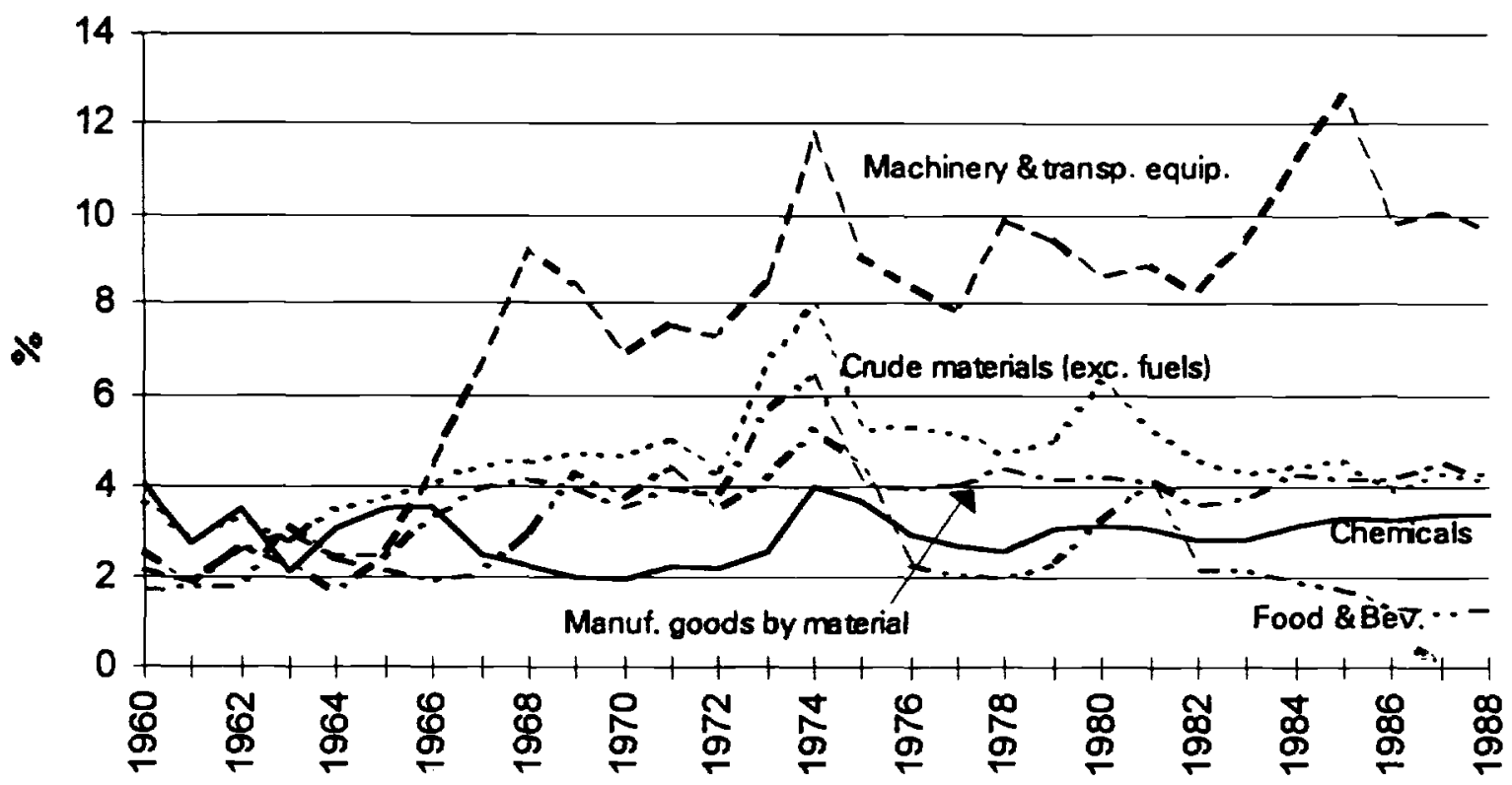

Figure 11 


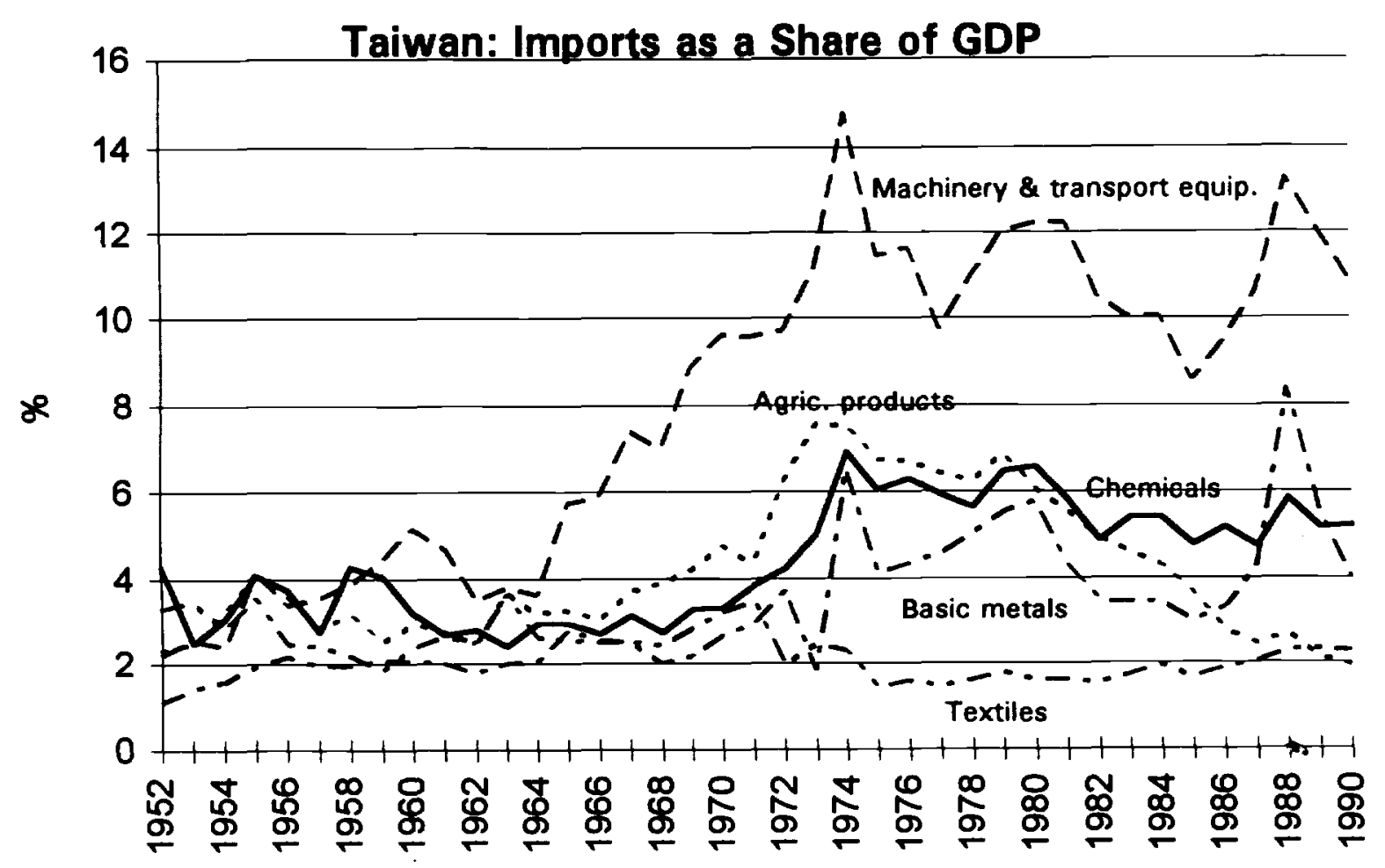

Figure 12 